\title{
An in silico study on molecular level interactions of host Siderocalin with siderophores from Mycobacterium tuberculosis and other bacterial species
}

\author{
Tanu Goyal, Sharmila Anishetty ${ }^{*}$ \\ From 2nd International Science Symposium on HIV and Infectious Diseases (HIV SCIENCE 2014) \\ Chennai, India. 30 January - 1 February 2014
}

\section{Background}

Tuberculosis (TB) drug research and development has witnessed resurgence in recent times primarily due to the high mortality rates despite the availability of front line drugs and a prominent BCG vaccine. Synergy of TB with HIV is another factor which has warranted a search for newer therapeutic interventions. Treatment of latent TB infection is also the need of the hour. Iron acquisition is an important virulence mechanism of Mycobacterium tuberculosis (MTB). To scavenge iron, bacterial species have developed high affinity, low molecular weight iron chelators termed as siderophores. To counteract the detrimental effect of microbial iron acquisition systems, the host secretes a $21 \mathrm{kDa}$ lipocalin protein (Siderocalin) that binds with these iron laden siderophores in an attempt to restrict the growth of MTB within host macrophages.

\section{Methods}

In the current study, using molecular docking tools, we assessed the interactions of host Siderocalin with Mycobactin, Parabactin and Cepabactin structurally non similar siderophores from three different bacterial speciesMTB, Paracoccus and Burkholderia cepacia. A comparison of molecular level interactions of Siderocalin with these siderophores was performed.

\section{Results}

Siderocalin forms energetically favourable and stable complexes with parabactin and cepabactin. However the

\footnotetext{
* Correspondence: s_anishetty@annauniv.edu
}

Centre for Biotechnology, Anna University, Chennai, India unfavourable positive binding energies for mycobactin- a salicylate derived MTB siderophore indicated that siderocalin does not dock well with mycobactin.

\section{Conclusion}

Siderocalin probably fails to disrupt the role of mycobactin in acquiring iron for mycobacteria thereby helping the pathogen to survive leading to progression of disease.

Published: 27 May 2014

\section{doi:10.1186/1471-2334-14-S3-015}

Cite this article as: Goyal and Anishetty: An in silico study on molecular level interactions of host Siderocalin with siderophores from Mycobacterium tuberculosis and other bacterial species. BMC Infectious Diseases 2014 14(Suppl 3):O15.

\section{Submit your next manuscript to BioMed Central and take full advantage of: \\ - Convenient online submission \\ - Thorough peer review \\ - No space constraints or color figure charges \\ - Immediate publication on acceptance \\ - Inclusion in PubMed, CAS, Scopus and Google Scholar \\ - Research which is freely available for redistribution \\ Submit your manuscript at www.biomedcentral.com/submit}

